DOI: https://doi.org/10.3126/njdrs.v15i0.31594

\title{
Focus and Locus of Pilgrimage Tourism at Santaneshwor Mahadev Temple, Lalitpur
}

\author{
Gopal Khadka \\ Lecturer at Department of Rural Development, Patan Multiple Campus, Lalitpur \\ Email for correspondence: khadkajigopal@gmail.com
}

\begin{abstract}
This study explains prospects and constraints of pilgrimage tourism at Santaneshwor Mahadev temple located in Godavari Municipality, Lalitpur. In doing so, quantitative case study methodology is applied. Necessary data are collected from 123 respondents (60 local residents, 60 tourists \& 3 hotel owners) selected convenniencely, randomly and purposively. The result indicates that this temple is famous from religious and cosmological view points. And also famous for becoming 360 degree scenic view points having good networking of road accessibility. Tourist arrival in the study area is favorable in all season. However, tourism activities in this area found minimum. Majority of the local people belongs to Brahman caste and engaged in subsistence farming. They have no clearcut idea for developing and promoting tourism activities. There is lack of basic tourist facilities like; tourist center, modern toilets, clean drinking water, restaurants, accommodation facilities, foreign exchange etc. Hence, awareness programs should be implemented in local communities and different facilities must be offered for promoting religious tourism. And better to prepare master plan by concerned authority to make Santaneshwor Mahadev temple as attractive pilgrimage tourism destination.
\end{abstract}

Key words: pilgrimage, focus, locus, tourist destination, prospects, constraints

\section{Background}

Generally the beginning of tourism in each country started with pilgrimage or religious tourism (Bhatia 1994). Even now, especially in Asia, religion is the strongest motive to travel. For the last two thousand years Chinese and Tibetan had been visiting Lumbini. But due to difficult terrain, the number was limited. Nepal is generally known as the birth place of Sita and Buddha. It is also known as the abode of Lord Shiva and the country of living goddesses. Nepal is also known as Sangri-La. There are places of great natural beauty, medieval age culture with great mythological base. To experience religious values and supreme natural beauty one has to trek to Santaneshwor Mahadev Temple in Jharuwarashi. The natural monument and pre-historical temple are mostly in the open air. The feeling or experience gaining in this place is totally different. When we reach the top of the hill, we will feel like being in paradise. We can enjoy the entire views of Kathmandu Valley and can see the beautiful sunrise view if we reach early in the morning. Hiking will be worth when we observe idols of different Hindu Gods and Goddesses that reflects the pre historic time. The decoration of the temple and stone paved stair cases to the temple gate will obviously remove our fatigue. 
Tourism is a smokeless industry, which plays significant role for the economic, socio-cultural, environmental, educational and political development of the nation. Tourism takes part in the pivotal role between national and international community (Tuladhar, 2008). Before industrial revolution, travel was mainly a matter of seeking knowledge, engaging in trade and commerce and undertaking pilgrimage. The industrial revolution caused technological changes, which influence in the social, political, economic and cultural life of human being. The industrial revolution also brings the change in the sector of tourism with the power driven machine. The consumption of such power driven machine attracts tourists from one place to another to fulfill their expectation and desire of entertainment (Satyal, 2002).

Tourism is an important source of foreign exchange, which contributes to generate employment and government revenue. It supports at local products like handloom, handicrafts, woolen products, herbals and many more things. It supports to increase demand for goods and services, which promotes supply of production and gives changes to improve the local traditional industries. Today it is looked on as Nepal's single most prized "economic commodity" the selling of which earns the country its valuable foreign exchange and generates a good income in the form of revenue (Sharma, 2009). When we turn the history of tourism in Nepal, we found that tourism industry was only well flourished in post 1950s. Prior to 1950 s tourists were only visited exotic places for their different objectives by which they documented the information on the different historical and religious places of Nepal. They just visited different areas of Nepal to see beauty and observing the cultural heritage.

In early years the country had no infrastructure, communication and other supporting facilities, which could not success to establish tourism as an attractive industry (Malla, 1998). Tourism industry plays a significant role for the promotion and generates additional employment opportunities like to run the business, tourist guide, and so on. For long run, development of pilgrimage tourism would be provided new facilities for the tourists like accommodation, communication, road, information, skilled guide and trekking facilities (Upadhaya, 2008). These facilities should not only confine in the city area but also other pertinent area of tourism like Santaneshwor Mahadev Temple area at Jharuwarashi in Godawari Municipality, Lalitpur. It is one of the religious destinations for Hindu devotees as well as for tourist. There is a large horde of devotees in the month of July and August to worship Lord Shiva. Devotees visit the Santaneshwor Mahadev Temple throughout the year. The few numbers of tourist arrivals and short stay of tourists indicate that a wide research is needed in this area to find out the main problems and prospects of tourism. That will be helpful to reduce the poverty and backward situation of Jharuwarashi and it supports to earn the foreign currency through this smokeless industry.

\section{Objectives}

- To explore the overall situation of Santaneshwor Mahadev temple.

- To assess the prospects and constraints of pilgrimage tourism in study area.

\section{Methodology}

Under quantitative research approach, this study related case study methodology for selecting respondents as case study research involves the study of an issue explored through the respondents within a bounded system, setting or context (Creswell, 2014). Case as "a bounded system" and inquire into it "as an object rather than a process". It is a specific or a complex functioning thing like; boundary and working parts and purposive social interactions (Stake, 1995, p. 2 as cited in Yazan, 2015). More 
so, case study can fit well with the needs of small-scale research through concentrating effort on one research site and helps a researcher to directly examine the data within a specific context (Denscombe, 1998).

In this study, selected 123 respondents (Table 1) are regarded as unit of study. And their responses on research issues are unit of analysis. Finally, the unit of analysis helped to explain on research situation (Merriam, 1998, p. 22 as cited in Yazan, 2015). More so, both primary and secondary sources are used to collect data and information. In order to analyze collected data, simple descriptive and illustrative statistical tools have been used.

Table 1. Sampling and Population

\begin{tabular}{llllll}
\hline S. N. & Category & $\begin{array}{l}\text { Sample } \\
\text { Population }\end{array}$ & $\begin{array}{l}\text { Sample } \\
\text { Number }\end{array}$ & Percent & Method \\
1 & $\begin{array}{l}\text { Tourists (arrived in } 3 \\
\text { days) }\end{array}$ & 60 & 40 & Convenience \\
2 & Local residence & 150 & & & \\
3 & Hotel owners & 5 & 60 & 60 & Simple Random. \\
Total & & $\mathbf{2 5 5}$ & $\mathbf{1 2 3}$ & 60 & Purposive \\
\hline
\end{tabular}

(Field Study, 2018)

\section{The Focus: Santaneshwor Mahadev Temple at a Glance}

Santaneshwor Mahadev temple is one of the religious destinations for Hindu devotees. It lies in Jharuwarashi of Godawari Municipality, Lalitpur district. Its height from the surface of sea level is 1400 meter and from the surface of land of its village is 100 meter. There is Mahankal temple in the east as the secondary temple just below of Santaneshwor temple.100 numbers of Shivalinga shrines seen south-east of the temple and the other monuments like Naag shrine in north and inn in south. During the month of July to August the temple is horded with devotees all day around to worship God Shiva as well as there is fair in this month. It is believed that the people who do not have their children, once they please Shiva at Santaneshwor Mahadev Temple then their lap would not get barren. These days it has become famous peaceful place to get away from the hustle and bustle of the city.

Everywhere we can see clean and green environment with dense forest where we can hear the sweet chirping of beautiful birds.

According to Hindu holy book Shree Swasthani Batra Katha, when Sati Devi immolated herself, furious Shiva carried her body clasped tightly to his heart. Other Gods called upon Lord Vishnu to return Shiva to sanity. Lord Vishnu used his Sudarshana Chakra to cut Sati's lifeless body into 52 pieces which fell down on earth at various places. These 52 places are called Shakti Peethas, and became places of pilgrimage. It is believed that one part of her body fell down on the top of the hill, where Santaneshwor Mahadev is located today. Thus the name of the temple was given a name Santaneshwor, means boon for having a baby.

This temple is situated on the western bank of River Karmanasa. It is built in the Nepalese Pagoda style of architecture. All the features of pagoda style are found here like cubic construction, beautifully carved wooden rafters on which they rest. The two level roofs are of copper covering. The temple resides on a square base platform with gold covering to pinnacle. It has four main doors, all depicts Nepalese craftsmanship. It takes approximately 1 hour drive (about $11 \mathrm{~km}$ away) from Lagankhel. A 
huge mass of Hindu followers can be seen in the special occasions of "Month of Shawaran" "Ekadasi", "Maha Shivaratri", "Teej", "Bada Dashain", and other Hindu festivals. The temple is visited by people especially on Monday and Saturday.

Once you reach the top of the hill, you'll feel as if you are in heaven. From the top you can see the beautiful scene of entire valley. You can also see the panoramic view of the Sun rise from the top in the early morning. The Santaneshwor Mahadev Temple doesn't just end up to the top of the hill; from the north-east side of the hill, you'll see a concrete sloppy way to another hill with idols of different Gods and Goddess. You'll also find different animal shaped stones of pre-historic time, which carry their own distinctive identity.

\section{Result and Discussions: Situation Analysis of Tourism Services}

Most of the tourists $(80 \%)$ are domestic. Majority of tourist $(60 \%)$ visit this area for the religious belief. They spend minimum amount on this area during their visit. Most of them (90\%) prefer homely environment, cultural and traditional activities and natural beauty available in this area. Majority of them (65\%) are not satisfied with overall situation of infrastructure available in this area. The survey of the area has shown that accommodations facility available is of medium investment type and privately operated venture. 90 percent of the total accommodations available are of medium standard. The accommodation price varies amonghotels of different classes. Locals have dominant role in hotel operation. 80 percent hotels are run by local people. Food price in the hotelsnearby the temple area is cheaper than other tourist destinations in Nepal. All the necessary goods are found in local markets only for some goods hoteliers have to move to city areas. There is lack of refreshing events and entertainment. Most of the tourists $(75 \%)$ who stay in a hotel room expect refreshing events and entertainment programs for getting relaxation from the stressful conditions. There is low attention of local hotel in Cleanliness issues. Lodging rooms should have clean, odor-free, eco-friendly and spacious conditions. This would help to drive more visitors to hotel. As hospitality businesses are usually operated around the clock and choose to hire a professional cleaning service. There is no proper transportation facility in hotel. Hotels should be ready to provide transportation facility $24 \times 7$ from all the major pick-up points of a city or town. Even a small van from the major spots can make a huge improvement in hotel business management. Transport facility is a must for hotels situated in the remote locations.

\section{Prospects of Tourism}

Santaneshwor Mahadev Temple area has a basketful of variety of cultural practices, languages, castes and ethnics groups, which makes it as an attractive destination for the tourists of different motive like educational, historical, sociological, anthropological, religious etc. The destination offers beautiful and heart touching mountains, green hills and scene, village tour, different culture, peaceful environment, etc. Other fundamental attractions of tourism in this area are natural beauties, pleasant weather, colorful communities and their life styles with different languages, fairs, and dances, friendly behaviors of locals and their feast and festivals. This area is rich in cultural attractions. Basically traditional culture is a great motivation factor of attraction to tourists. Different fairs such as Sharwan Mela, Panchami Mela, Teej Mela are held once a year. It is more than just a religious destination. It is a combination of religion, art, and culture. It offers peace and devotion. 
Hundreds of rituals are performed here throughout the year. The temple premise is an open museum. It is highly recommended religious hub for a mix of religious, cultural and spiritual experiences. This temple is a great natural cantonment with outstanding scenic beauty and graceful charm. The location of temple is covered by green lands. Decoration of the temple, stone paved stair cases to the temple gate and pine forest areas are attractive and important for the tourism. Climate is basic primary elements for the development of tourism in any tourist destination. It has very pleasant and healthier climate throughout the year. As it lies in sub-tropical region there is neither very hot nor very cold. Most of the months in a year have bright sunshine and cloudless sky, which attracts tourists. Tourists want fine weather and warm sunshine. A good weather is important because it plays an important role making holiday pleasant.

\section{Constraints of Tourism}

Due to the lack of infrastructural development, there is low attraction of tourists. There is a great problem of water supply, improper sanitation program, lack of internet facilities, lack of allseason road network, lack of medical facilities, lack of well facilitate hotel and lodge, insufficient parking, lack of money exchange facilities and financial services, lack of conservation activities, lack of indigenous tourists goods. Absence of tourist information centre and publicity program is another constraint for the promotion of tourism in this area. The information centre should be well equipped and facilitated with information technology, information services and documents. There is not well or enough program for the publicity of this area. There is Lack of facilities and safety for tourists. Different types of security challenges faced by tourist in this area are like as general theft and other crime, public violence, cybercrime issues, sexual abuse on women, racial discrimination, risk of food poisoning etc. Apart from this, the hindrance factors of tourism in this area are lack of trained tourism related human resources, lack of local awareness about tourism and its impacts, terrible traffic jam, political conflicts, strikes and political movement etc.

\section{The Locus: Overall Reflections}

Tourism is the combined product of various factors. All factors should be analyzed minutely to find out the holistic figure. Integrated analysis help to find out the reinforcing and hindering factors of tourism development. The results of integrated analysis in terms of tourism promotion and development in Santaneshwor Mahadev Temple area are as mentioned below (Table 2).

Table 2. Overall Reflections of the Study

\begin{tabular}{|c|c|c|}
\hline \multirow{3}{*}{$\begin{array}{l}\text { Factors } \\
\text { Environmental }\end{array}$} & Themes & Reflections \\
\hline & Climate & $\begin{array}{l}\text { Climate is one of the most fascinating features for any places } \\
\text { of tourist attraction. Such a climate with ample of sunshine } \\
\text { and warmth attracts tourists who come from the temperate and } \\
\text { colder regions. Santaneshwor Mahadev Temple area is alsoa } \\
\text { noble location adorned by neither too hot nor too cold means } \\
\text { pleasant climatic characteristics. }\end{array}$ \\
\hline & Scenery: & $\begin{array}{l}\text { Tourism booms at spots with beautiful sceneries. This area } \\
\text { contains ample of beautiful natural sceneries on all around } 360 \\
\text { degree. }\end{array}$ \\
\hline
\end{tabular}

Nepalese Journal of Development and Rural Studies, Volume 15, 2018 


\begin{tabular}{|c|c|c|}
\hline conomic & Accommodation & $\begin{array}{l}\text { Of all socio-economic factors, accessibility is the most important } \\
\text { one. All tourist centers must be easily accessible by various } \\
\text { modes of transportation. This area also has road accessibility } \\
\text { leading from Kathmandu, Patan and Bhaktapur to the temple. } \\
\text { This area lacks accommodation facilities. Places of tourists' } \\
\text { interest must be capable enough to provide good accommodation } \\
\text { and catering facilities. Generally, tourism mostly prospers in } \\
\text { those areas where good lodging and food facilities are available } \\
\text { at reasonable prices. }\end{array}$ \\
\hline \multirow[b]{3}{*}{ Cultural } & Amenities & $\begin{array}{l}\text { This area has required various amenities for the growth of } \\
\text { tourism like skiing, roping, paragliding, rowing, fishing, surfing, } \\
\text { safari adventure, emergency facilities and so on. }\end{array}$ \\
\hline & Ancillary services & $\begin{array}{l}\text { This area has absence of ancillary services for the promotion of } \\
\text { tourism. If a tourist destination is equipped by supplementary } \\
\text { services like banking and finance, the internet and telecom } \\
\text { connectivity, hospitals, insurance and so on, then such a place } \\
\text { succeeds to hold more tourists for a longer time. This helps to } \\
\text { boost the local economy to some extent. }\end{array}$ \\
\hline & $\begin{array}{l}\text { History } \\
\text { And } \\
\text { religion }\end{array}$ & $\begin{array}{l}\text { This area has great historical and religious significance with a } \\
\text { legacy of rich cultural heritage. People often make pilgrims to } \\
\text { places of religious importance to seek inner peace, get blessing } \\
\text { of their favorite deities and gurus, attain salvation before death, } \\
\text { etc. Faiths, beliefs and sentiments of people contribute in } \\
\text { booming tourism in this area. } \\
\text { On the basis of integrated analysis, there is high potentiality to } \\
\text { promote pilgrimage tourism in this area. }\end{array}$ \\
\hline
\end{tabular}

(Developed by the Researcher, 2018)

\section{Conclusion}

Santaneshwor Mahadev temple is not yet recognized and prescribed as a major tourist destination in Kathmandu valley. Now it is essential to develop this area as a vital pilgrimage tourist destination by realizing its environmental, socio-economic and cultural significance. Tourism has provided self employment opportunities for local residents including farmers. It provides a means and an incentive for investment in infrastructure such as roads, vehicles, local medical and education facilities. Environmental conservation and promotion is boosted up in this area through tourism. It can provide economic incentives for a place to preserve maintain and regenerate the environment in natural settings. Cross-cultural exposure and understanding is developed by tourism among the local residents. It promotes international connections which can bring more business and cultural collaborations in long run. It also promotes cross-cultural awareness for both locals and tourist and builds bridges of understanding between cultures. It puts a place on the map.

Nepalese Journal of Development and Rural Studies, Volume 15, 2018 
Hence, it is essential to establish tourist information centre to guide and help tourists as soon as possible. Santaneshwor Mahadev temple development trust and tourism master plan and action plan should be prepared through the broad participation of stakeholder. Standard of the hotels should be increased. Tourist oriented programs should be launched. Publicity through various media should be done to make this area popular and make it important tourist destination. Tourist guide facility should be improved by hiring trained people or experts in temple area. Establishing the tourist recording system andfocusing on effective programs to increase the number and frequency of tourist are equally essential.

\section{References}

Bhatia, A. K. (1994). International tourism. New Delhi: Sterling Publication.

Bramwell, B., \& Lane, B. (1993). Sustaining tourism: An evolving global approach. Journal of Sustainable Tourism, 1(1), 1-5.

Creswell, J. W. (2014). Research design, qualitative, quantitative, and mixed methods. USA: Pearson Education Inc.

Denscombe, M. (1998). The good research guide for small-scale social research projects.

Faibrbrie, R. (1968). Tourism management. Canada: University of Waterlook and Faculty of Environmental Studies.

Ghimire, R. P. (2009). Contemporary issues of tourism development in Nepal. Kathmandu: Nathm Publication.

Godfry, W., \& Clack, M. (2009). Eco-tourism and sustainability-opportunities and challenges in the case of Nepal. Sweden: University of Uppsala, International School of Tourism and Hotel Management.

Kunwar, R. R. (2006). Tourists and tourism, science and industry interface Kathmandu:

Malla, S. M. (1998). A study on planned development of tourism in Nepal (Unpublished Master's Thesis, Tribhuvan University). Kathmandu: Faculty of Humanities and Social Sciences.

Pradhan, K. M. (2008). Macro and micro perspective of tourism in Nepal. Kathmandu: Benchmark Educational Support Pvt. Ltd.

Satyal, A. R. (2002). Pilgrimage tourism in Nepal, New Delhi: Droit publishers.

Sharma, A. S. (2009). Tourism management. New Delhi: Essential Books.

Sharma, S., Vredenburg, H., \& Westley, F. (1994). Strategic bridging: A role for the multinational corporation in third world development. Journal of Applied Behavioral Science. 27(1), 6590.

Tosun, C. (2001). Challenge of sustainable tourism development in the developing world: The case of Turkey. Tourism Management, 22, 289-303.

Tuladhar, G. (2008). Vision and mission of village tourism: Kathmandu: VITOF- Nepal Publication.

UNWTO (2004). Indicators of sustainable development for tourism destinations: A guidebook. Madrid: World Tourism Organization.

Upadhaya, R. (2008). Tourism and economic development in Nepal. New Delhi: Northern Book Centre.

Yazan, B. (2015). Three approaches to case study methods in education: Yin, Merriam, and Stake. The Qualitative Report, 20(2), 134-152.

Nepalese Journal of Development and Rural Studies, Volume 15, 2018 